\title{
A Review of Solo Taxonomy on Students' Errors in High Mathematical Abilities in Calculating Definite Integral of Trigonometric Functions
}

\author{
Rosa Mery Christinove, Helti Lygia Mampouw
}

Universitas Kristen Satya Wacana Salatiga; helti.mampouw@uksw.edu

\begin{abstract}
The aim of this research is to review students' error in calculating the definite integral of trigonometric functions using Solo Taxonomy. This research is descriptive qualitative research. The results of the study show that the most errors done by the students are at the multi-structural level caused by the addition errors and the lack of subjects' accuracy. Errors at the pre-structural level are the errors done by the subjectswho do not understand the purpose of the problems given. At the uni-structural level, the subjects make mistakes by applying the concept from the beginning of the problem. At the relational level, the subject uses a concept that is not common to solve problems but it has passed through several steps of completion. The results of this study can be a reference to anticipate and reduce students' errors in calculating the definite integral of trigonometric functions.
\end{abstract}

Keywords: Error; Solo Taxonomy; Integral Trigonometry

\section{INTRODUCTION}

A definite integral of trigonometric functions is one part of certain integral topics taught at the high school level. Understanding the concepts of trigonometric identity formula strongly supports the success of learning in certain integrals of trigonometric functions. Based on the data on the high school students, the national exam result for the 2014/2015 academic year shows an unsatisfying result in calculating the definite integral of trigonometric functions.From 4 national exam questions on integrals in the 2014/2015 academic year of senior high school level (SMA), the lowest score obtained by several cities in Central Java. The same phenomena also happened at the provincial and national scale. The result of pre-research obtained when the researcher conducted an internship at one of the high schools in Salatiga showed the same result. Figure 1 shows two ways of how thestudents solved the problem. From the same problem, the two students displayed different solutions but gave the same final results.

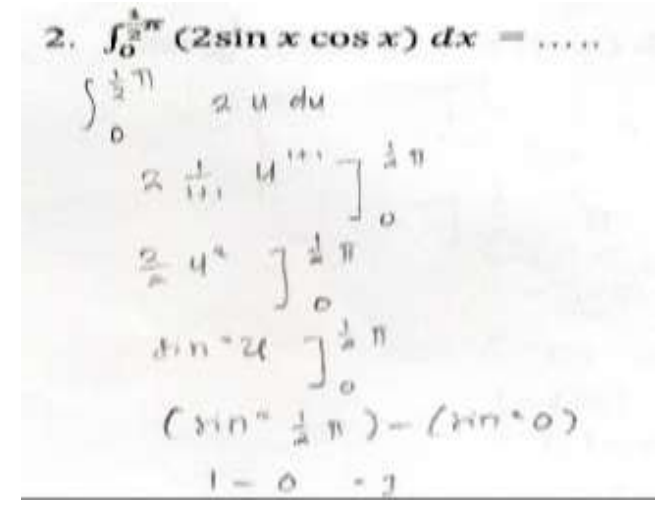

a. Completion by BT

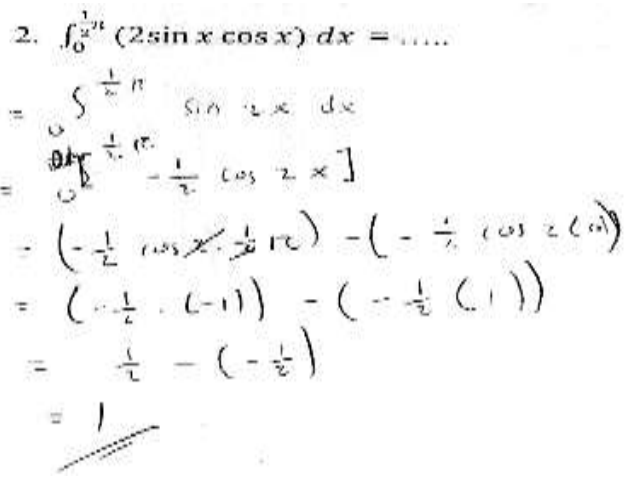

b. Completion by SF

Figure 1. Variation in how Students Solve the Problems of Calculating Definite Integral of Trigonometric Functions 
According to Piaget's cognitive development, a high school student should have possessed formal operation with better abstract thinking and hypothetical abilities. (Sunarno \& Hartono, 2009) But the ability to think abstractly that is less based on problem-solving skills can have a crucial impact when they are at the college level. The type of students' error in solving informatics mathematical problems in integral material is due to conceptual errors in identifying types of integral questions, the operational errors are in the form of multiplication operations, principle errors are error in integrating fraction function, error in the process of transforming the results of the example into the form needed by the question. (Arvianto, 2017)

One way to analyze student errors is to use the SOLO taxonomy (Structure of the Observed Learning Outcome Taxonomy). It systematicallydescribes how a person's performance grows in complexity when mastering many tasks, especially the types of tasks performed in school. It can be used by teachers to identify the complexity and quality of the expected outcome generated by the students.

Many studies have been carried out in increasing students' abilities especially in integral and trigonometric material (Anggraini \& Masykur, 2018; Arifudin, Wilujeng, \& Utomo, 2016; Arvianto, 2017; Hartono \& Noto, 2017; Misrianti, Sugiatno, \& Hamdani, 2014; Nurhikmah, Menurut, \& Tentu, 2016; Putra \& Anggraini, 2016; Rumasoreng \& Sugiman, 2017; Susilo \& Khabibah, 2013) because trigonometric material is considered important to be mastered as well as research that analyzes students' errors by reviewing it using Solo Taxonomy (Azizah, 2015; Ghati, 2018; Lipianto et al., 2013; Manibuy, Mardiyana, \& Saputro, 2014; Pesona, 2018; Rosyida Ekawati dkk, 2013; Tarigan, 2014; Widyawati, Afifah, \& Resbiantoro, 2018) However, there has been nostudy that reviews students' error in calculating the definite integral of trigonometric functions using Solo Taxonomy. So, this study aims to review students' error in calculating the definite integral of trigonometric functions using Solo Taxonomy.

\section{THE RESEARCH METHODS}

This study is a descriptive qualitative study because the data collected is in the form of sentences and elaboration of answers to the subject which is the description of subjects'observable behavior.

The research subjects consisted of two twelfth grade students with high mathematical abilities who had already studied definite integral of trigonometric functions. The research subjects were given the initialsas S01 and S02. The main instrument of this research was the researchers themselves. The additional instruments consisted of test items and semi-structured interview guidelines. The test questions contained five definite integral questions of trigonometric functions taken from the questions of senior high school national examination in 2012 to 2015.

The five test questions were 1) the values of $\int_{0}^{\pi} \sin 2 x \cos x d x=\cdots, 2$ ) the value of $\left.\int_{0}^{\frac{1}{2} \pi}(2 \sin x \cos x) d x=\cdots, 3\right)$ the value of $\left.\int_{0}^{\frac{1}{2} \pi}(2 \sin 2 x-3 \cos x) d x=\cdots, 4\right)$ the value of $\int_{0}^{\frac{\pi}{3}}(\sin 5 x+\sin x) d x=\cdots$ and 5$)$ the value of $\int_{0}^{\frac{\pi}{6}}(\sin 4 x \cos 2 x) d x=\cdots$. 
The analysis using Solo Taxonomy was carried on the valid and confirmederrors done by the subjects. Every error was mapped based on the level of structural, uni-structural, multistructural, relational, and expanded abstract which later would be described.

\section{THE RESULTS OF THE RESEARCH AND THE DISCUSSION}

Solo taxonomy is one of the taxonomies of learning objectives which distinguishes it from other taxonomies as a way of looking at educational goals.Biggs, J.B., dan Collis (1982) design Solo Taxonomy (Structure of Observed Learning Outcomes) as an evaluation tool of the student responses' quality toward a task. Biggs \& Collis mention that there are five levels of Solo Taxonomy, namely:

1. Pre-structural: Students do not understand the question so that in solving problems, they tend to use methods that are irrelevant or unclear

2. Uni-structuralmethods: Students use one problem solving to solve the problem.

3. Multi-structural: Students use two pieces of information or more to solve problems correctly but cannot combine them together.

4. Relational: Students think using two pieces or more information on the question and connect it to solve the problem correctly.

5. Expanded Abstract: students think inductively and deductively. They use two pieces of information or more and connect the information to draw conclusions to build new concepts and apply them.

Each level of Solo taxonomy refers to the need for a number of working memory or attention span because at a higher level, there are not only aspects of a situation that needs to be considered but also more relationship between aspects of the actual situation and hypothesis. The aim of Solo Taxonomy is to provide a systematic way of describing how students' performance grows in a structural complexity when handling and mastering various tasks. Solo taxonomy can be used to improve learning outcomes by adding quality results from feedback.

The recapitulation of the final score of definite integral trigonometric functions test is shown in Table 1. The results were then analyzed and further described based on the level of Solo Taxonomy.

Table 1. The Summary of the Subjects' Final Answers toward Five Definite Integral Trigonometric Functions Problems

\begin{tabular}{ccccccc}
\hline Subjects & Item 1 & Item 2 & Item 3 & Item 4 & Item 5 & Incorrect Final Answer \\
\hline S01 & S & B & B & S & S & 3 \\
S02 & B & B & B & S & S & 2 \\
\hline
\end{tabular}

Description:

B: Correct Final Answer S: Incorrect Final Answer

\section{Pre-structural Level}

The error did by S02 at the pre-structural level was found in question number 5. S02 did not understand the meaning of the question correctly since he wrote the questions three times. 
Though the ideal answer to the problem could be answered using the trigonometric multiplication formula $2 \sin A \cos B=\sin (A+B)+\sin (A B)$ before being integrated. This shows that S02 used the wrong formula. Salmina stated that the common error in calculating trigonometric substitution integral isin determining the trigonometric integral formula (Salmina, 2017). After that, S02 immediately wrote the next step on the fourth line, namely $-\cos (2 x)^{3}$ and concludes the answer as-3. From the S02's test answers and interviews, it canbe seen that S02 did not understand the objective of the problem and preferred to solve the problem in an unclear manner. At this level, the error made by the subject is an error in understanding the problem. The indicator of errors at the pre-structural level is the tendency of subjects who do not understand the objective of the problem, do not solve the problem, or solve the problem in a way that is not relevant or using unclear methods. Subjects with poor ability do not reach the uni-structural level caused by the error factors in mastering concepts, principles, and operations.(Manibuy et al., 2014) Answer S02 is shown in Figure 2.

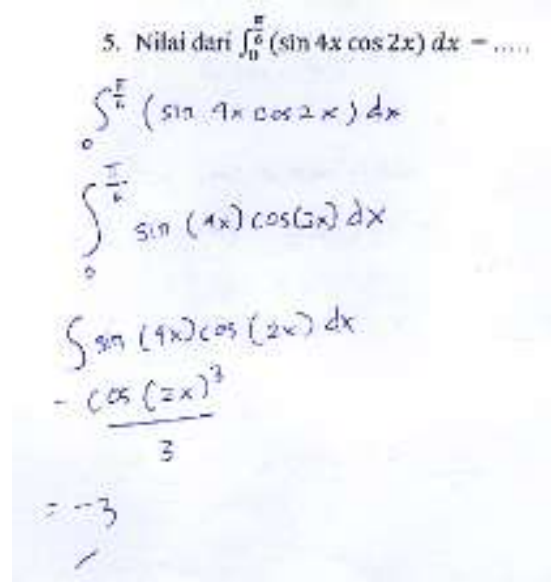

Figure 2. The Question and Answer of Item Number 5 Done by S02

\section{Uni-structural Level}

Error at the uni-structural level occurred when S01 worked on problem number 5. S01 experienced limited understanding of concepts and resulted in the use of only one concept of completion that is the same as the previous question. This thing affected the answers obtained to be incorrect from the beginning to the end. In line with research by Lipianto the misconception experienced by class VII students is the lack of mastery towards the square and rectangle concepts. (Lipianto et al., 2013). It can be seen from the third row of the SO1's test result, S01 substitutes $\cos 2 x=u$ and $2(-2 \sin 2 x)=d u$ where the ideal answer has changed the calculation into trigonometric multiplication formula $2 \sin A \cos B=\sin (A+B)+\sin (A B)$ before being integrated. At this level, the ideal condition is to use a piece of information from the problem and use it to solve the problem. The most dominant errors at the uni-structural level are the concepts, principles, and skills errors. (Rumasoreng \& Sugiman, 2017). The answer to question number 5 is shown in Figure 3. 


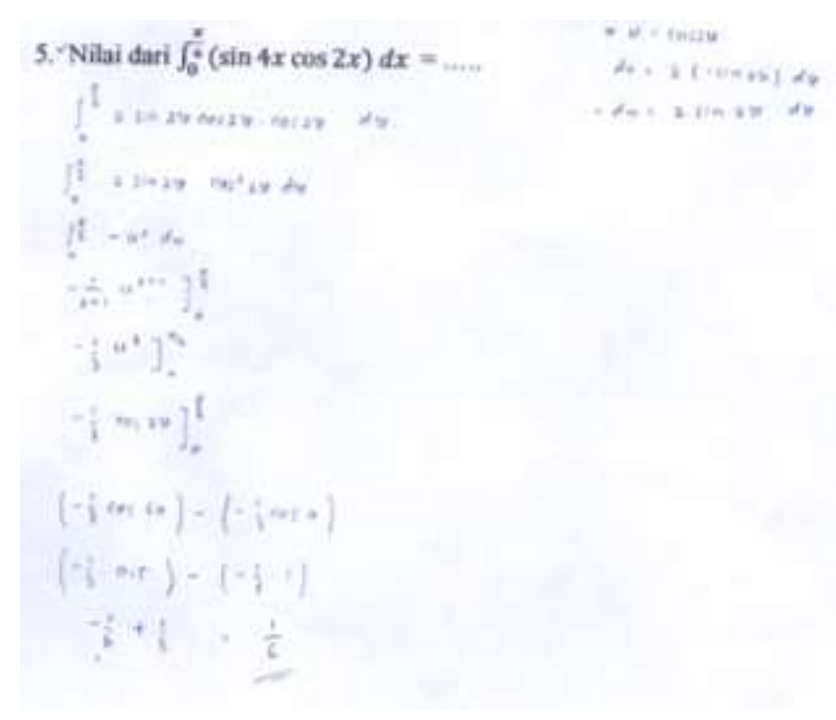

Figure 3. Question and answer number 5 done S01

\section{Multi-structural Level}

The error made by S01 when working on question number 1 belongs to the multistructural level. S01 experienced a misunderstanding of the concept of addition of fraction when explaining the result of $\frac{2}{3}+\frac{2}{3}=\frac{4}{6}$ during the interview. S01 answeredthe question using the concept of trigonometric substitution by specifying $u=\cos x$ and $d u=-\sin x$. From the third line to the seventh row, S01 solved the problem using the correct steps. The error made by S01 is a calculation error in the fraction addition section. It says that $\frac{2}{3}+\frac{2}{3}=\frac{4}{6}$, even though the correct answer is $\frac{4}{3}$. It can be seen that S01 actually understood the objective of the question, but due to a misunderstanding of the concept of addition, resulting in the incorrect final answer.

Still, at the same level, the errors done by S01 and S02 while working on question number 4 were found. The error done by S01 was not writing the next step after the second line was written which resulted in calculation errors. This is supported by Pesona who concludes that at this level, the subject is having difficulty in processing and using information (Pesona, 2018). S01 answered question number 4 using the concept of the definite integral of trigonometric functions where S01 integrated $\sin 5 x$ into $-\frac{1}{5} \cos 5 x$ and $\sin x$ becomes $-\cos x$. Ideally, the writing of the third step is to substitute the value of $x$ with the upper and lower limits known in the problem. This affected the answer of the subjects in the next step where they made errors in determining the value of $\cos \frac{\pi}{3}$, which should have been answered $\frac{1}{2}$, but they wrote $-\frac{1}{5}$ instead. Similarly, when determining the value of $-\frac{1}{5} \cos 0$, the answer should be $-\frac{1}{5}$, but they answered -0.5 .

Same as S01, the error done by S02 was a calculation error. In line with Rahmawati's research (2017) were one of the subjects made an error in the calculation process. S02 did not write down the results of $-\frac{1}{5} \cos \frac{5 \pi}{3}$ and $-\frac{1}{5} \cos 0$. In the sixth line of the subject's answers, it can 
be seen that the answerwas directly the final result. This caused S02 to experience a calculation error which should have been answered $\frac{3}{5}$ but he answered $\frac{6}{5}$ instead. The indicators of this level are the subject are able to use several problem solving but cannot connect to the previously used solution. The error at the multi-structural level is a mistake in the calculation when working on a problem. The answer to the question is shown in Figure 4.

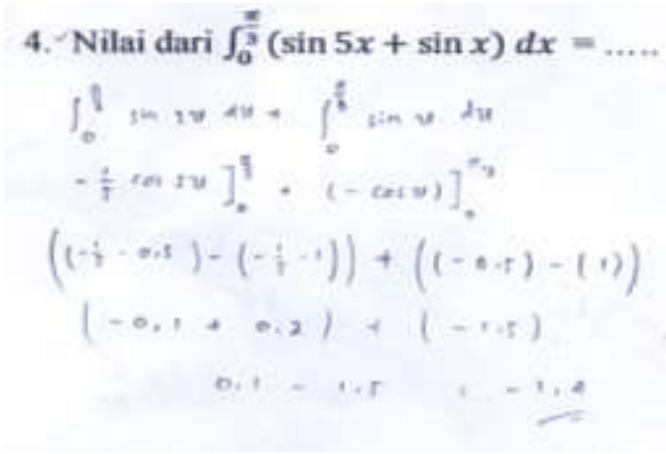

a. Answered by S01

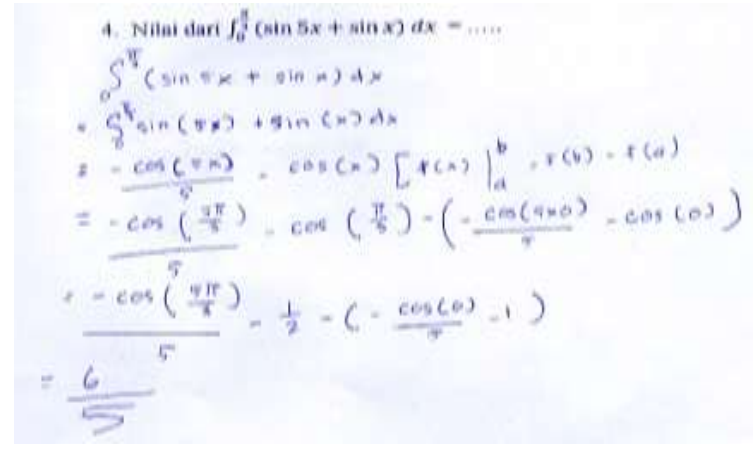

b. Answered by S02

Figure 4. Problem and Answer of Item Number 4 Done by S01 and S02

\section{Relational Level}

The error did by S02 at the relational level when answering question number 1 is using another concept although getting the right final answer. This is similar to the research by Tarigan who concludes that the error done by subjects in working on geometry problems is using improper procedures. (Tarigan, 2014) The subject did this by integrating $\sin 2 x$ and cosxseparately, thus, he got an incorrect answer description.Question number 1should be answered using the concept of trigonometric formula $\sin 2 A=2 \sin A \cos A$. The answer provided by $\mathrm{S} 02$ turns out that the correct end result is $\frac{4}{3}$. This is in line with Pratiwi's research on the conclusion that the subject's relational level can connect data which then applies the concept and can make relevant conclusions.(Pratiwi, 2015)

In addition, S02 understood the objective of the question but cannot provide a clear explanation although finally, he got the correct final answer. The indicators of this level are the ability to use two pieces of information or more and solving them correctly. The subject can determine the formula used to find the solutions. The subject's answer is shown in Figure 5.

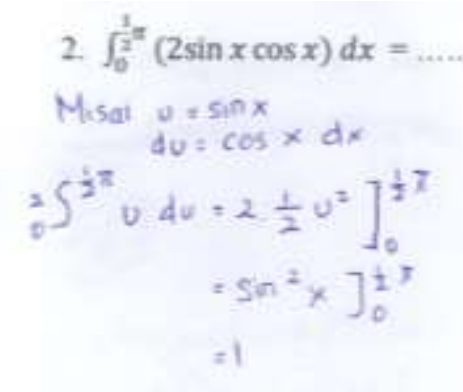

Figure 5. Questions and Answers of Item Number 2 Done by S02 


\section{Expanded Abstract Level}

S01's answeron item number 2 is included in the expanded abstract level because he has solved the problem with the right procedures and answers. S01 did the problem by specifying $u=\cos x$ and $d u=-\sin x d x$. S01 answered the question using the right steps and got the right answer. This shows that the subject understood the objective of the problem and can solve the problem correctly. The subject's level is the expanded abstract since he could implement problem-solving strategies.

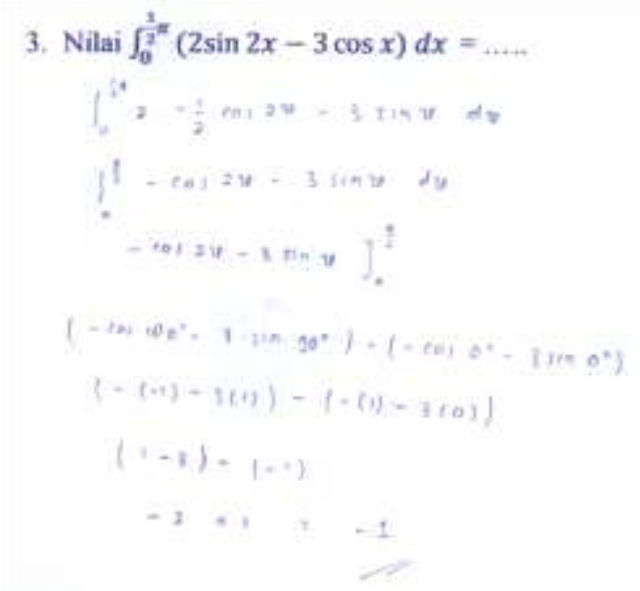

a. Answered by S01

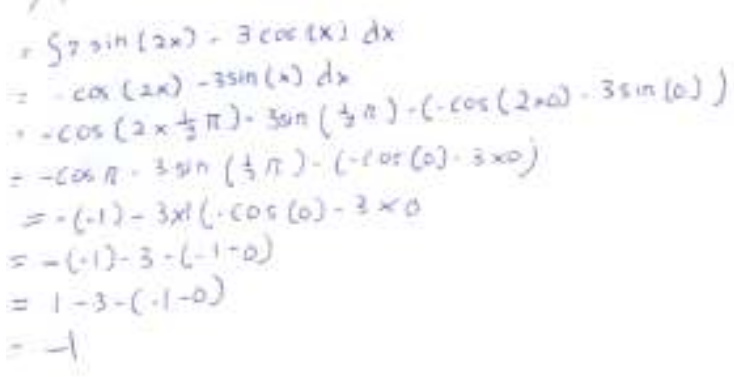

Figure 6. Question and Answer of Item number 3 done by S01 and S02

In addition, the answers from S01 and S02 in answering question number 3 are also included in this level. There is a difference in the way of working between S01 and S02. The difference is found in the first row. S01 chose to directly integrate question number 3. S02 also integrated it after writing the question on the first line. S01 immediately wrote the description of $-\cos 2 x-3 \sin x d x$ by substituting the value of $x$ with the upper and lower limits, the same thing was also done by S02 The final results of the two subjects' answers are the right answers with the correct steps. The ideal condition of this level is that the subject is able to understand the questions correctly and can solve the questions correctly. This indicates that the subject has been able to work on the problems correctly. Rosyida Ekawati states that to reach the level of expanded abstract, the subject needs to understand the issues in question and using the data to solve the problem and do the correct calculation (Rosyida Ekawati dkk, 2013).

The previous study by Ghati concludes that Solo Taxonomy makes it easier for teachers to know the stage of students' development and do the mapping.(Ghati, 2018) The analysis using Solo Taxonomy can distinguish the types of errors made by the students in calculating definite integrals of trigonometric functions. It is hoped that this action can anticipate and minimize the errors so that the teacher could remediate the mistakes made by students. The role of the teacher is indeed very influential because the teacher can provide a context in which children are challenged to engage with activities that require adaptation that is appropriate to their level of development (Kuswana, 2012). The result of this study is expected to be a 
reference for teachers in developing mathematics learning especially the definite integral of trigonometric functions.

\section{CONCLUSION AND SUGGESTIONS}

Based on this research, out of five Solo Taxonomy stages, the highest numbers of errors arefound in the multi-structural level caused by the errors in the addition of fraction, the lack of accuracy in determining the value of the calculation, and the subjects did not write the calculation procedure which caused calculation errors. The expanded abstract level has the least errors made by the subjects, furthermore, the subjects could answer the problems using the correct completion steps which indicate thatthey have understood the objective of the problems and can use existing data to solve them.

It is suggested for the teachers or other researchers to reduce students' errors in the definite integral of trigonometric functions by paying attention to the prerequisites materials studied by the students.

\section{REFERENCES}

Anggraini, N., \& Masykur, R. (2018). Modul Matematika Berdasarkan Model Pembelajaran Problem Based Learning Materi Pokok Trigonometri. Desimal : Jurnal Matematika, 1(2), 217-228.

Arifudin, M., Wilujeng, H., \& Utomo, R. B. (2016). Pengaruh Metode Discovery Learning Pada Materi Trigonometri Terhadap Kemampuan Penalaran Adaptif Siswa SMA. Kalamatika, I(2), 129-140.

Arvianto, I. R. (2017). Kesalahan Mahasiswa Dalam Menyelesaikan Soal Integral Berdasarkan Gaya Kognitif. Jurnal Matematika Dan Pendidikan Matematika, 2(1), 36-47.

Azizah, F. R. (2015). Analisis Kemampuan Pemecahan Masalah Matematika Berdasarkan Taksonomi SOLO pada Sub Pokok Bahasan Balok Siswa Kelas VIII H SMP Negeri 7 Jember.

Biggs, J.B., and Collis, K. . (1982). Biggs' structure of the observed learning outcome (SOLO) taxonomy Teaching and Educational Development Institute Examples of different performances, $x i i+245 \mathrm{pp}$.

Ghati, E. W. (2018). Dengan Model Pembelajaran Berbasis Masalah Berdasarkan Taksonomi Solo, 5(2), 209-216.

Hartono, W., \& Noto, M. S. (2017). Pengembangan Modul Berbasis Penemuan Terbimbing untuk Meningkatkan Kemampuan Matematis pada Perkuliahan Kalkulus Integral. Jurnal JNPM ( Jurnal Nasional Pendidikan Matematika ), 1(2), 320-333.

Kuswana, W. S. (2012). Taksonomi Kognitif: Perkembangan Ragam Berfikir. Bandung: Remaja Rosdakarya.

Lipianto, D., Budiarto, M. T., Matematika, J., Surabaya, U. N., Matematika, J., \& Surabaya, U. 
N. (2013). Analisis kesalahan siswa dalam menyelesakan soal yang berhubungan dengan persegi dan persegipanjang berdasarkan taksonomi solo plus pada kelas VII. Mathedunesa, 2(1).

Manibuy, R., Mardiyana, \& Saputro, D. R. S. (2014). Analisis Kesalahan Siswa Dalam Menyelesaikan Soal Persamaan Kuadrat Berdasarkan Taksonomi Solopada Kelas X SMA Negeri 1 Plus Di Kabupaten Nabire - Papua. Jurnal Elektronik Pembelajaran Matematika, 2(9), 933-945.

Misrianti, B. F., Sugiatno, \& Hamdani. (2014). Wawancara Klinis Berbantuan Alat Peraga untuk Mengatasi Kesulitan Siswa Dalam Materi Perbandingan Trigonometri Di Sma. Jurnal Pendidikan Dan Pembelajaran Untan, 3(4), 1-11.

Nurhikmah, S., Menurut, K. K., \& Tentu, I. T. (2016). Menyelesaikan Permasalahan Integral Tak Tentu. Jurnal Tatsqif, 14(2), 218-237.

Pesona, R. I. dan T. N. H. Y. (2018). Deskripsi Kemampuan Matematika Siswa Dalam Pemecahan Masalah Sistem Persamaan Linear Dua Variabel Berdasarkan Level. Jurnal Genta Mulia, 9(1), 99-109.

Pratiwi, N. D. (2015). Pengembangan Instrumen Evaluasi Berbasis Taksonomi Structure of The Observed Learning Outcome (SOLO) Untuk Menentukan Profil Kemampuan Siswa Dalam Memecahkan Masalah Fluida Statis. Jurnal Inovasi Pendidikan Fisika (JIPF), 4(3), 45-49.

Putra, R. W. Y., \& Anggraini, R. (2016). Pengembangan Bahan Ajar Materi Trigonometri Berbantuan Software iMindMap Pada Siswa SMA. Al-Jabar: Jurnal Pendidikan Matematika, 7(1), 39-47.

Rosyida Ekawati dkk. (2013). Studi Respon Siswa Dalam Menyelesaikan Soal Pemecahan Masalah Matematika Berdasarkan Taksonomi SOLO. Journal of Mathematics Education Research, 2(2), 103.

Rumasoreng, M. I., \& Sugiman, S. (2017). Analisis Kesulitan Matematika Siswa Sma/Ma dalam Menyelesaikan Soal Setara Un Di Kabupaten Maluku Tengah. Jurnal Riset Pendidikan Matematika, 1(1), 22. https://doi.org/10.21831/jrpm.v1i1.2661

Salmina, M. (2017). Analisis Kekeliruan Dalam Menyelesaikan Soal Kalkulus Pada Mahasiswa Pendidikan Matematika. STKIP Bina Bangsa Getsempena, 4(2).

Sunarno, \& Hartono, A. (2009). Perkembangan Peserta Didik. Jakarta: Rineka Cipta.

Susilo, Y., \& Khabibah, S. (2013). Peningkatan Motivasi Belajar Siswa Melalui Model Pembelajaran Kooperatif Tipe Numbered Head Together ( Nht ) Materi Ajar Perbandingan Dan Fungsi Trigonometri Pada Siswa Kelas X. MATHEdunesa, 2(2), 1-8.

Tarigan, D. (2014). Taksonomi Solo dalam Analisis Kesalahan Menyelesaikan Soal Geometri Bagi Mahasiswa PGSD. Jurnal Pengabdian Kepada Masyarakat, 20(75), 34-39.

Widyawati, A., Afifah, D. S. N., \& Resbiantoro, G. (2018). Analisis Kesalahan Siswa dalam 
Memecahkan Masalah Lingkaran Berdasarkan Taksonomi SOLO pada Kelas VIII. Jurnal Pendidikan Matematika Dan Sains, VI(1), 1-9. 